71 巻 707 号 (2005 7)

\title{
ハーモニックウェーブレットによる定常振動波形の異常性検出*
}

\author{
井上卓 見*1, 金 元 啓 幸*2, 末 岡 淳 男*1 \\ 小田原 悟*3, 村 上 敬 宜*1
}

\section{Detection of an Abnormality in Steady-State Vibrations by Using the Harmonic Wavelet}

\author{
Takumi INOUE*4, Hiroyuki KANEMOTO, Atsuo SUEOKA, \\ Satoru ODAHARA and Yukitaka MURAKAMI
}

\footnotetext{
${ }^{* 4}$ Department of Intelligent Machinery and Systems, Kyushu University,

6101 Hakozaki. Higashi ku, Fukuoka-shi, Fukuoka, 812-8581 Japan
}

\begin{abstract}
This paper deals with the fault prediction of machines by detecting local abnormalities of the signal by using the wavelet transform. In this paper, the signal is a steady-state vibration waveform measured by an acceleration pick-up. The harmonic wavelet was used to detect the abnormalities of the signal. Then, it is necessary for applying the harmonic wavelets to remove the end effects and the unacceptable noise for the effective diagnosis. The authors proposed the method to remove the end effects and the noise from the signals by using the usual Fourier transform. The signals were limited to steady state waveforms and the abnormalities of the signals were periodical. As the result, it was made clear that the local abnormalities were able to be detected from the signals due to the slight collisions caused by loose bolt and the fatigue crack generated in the in-line flow-induced vibration.
\end{abstract}

Key Words: Diagnostics, Noise, Vibration Coupled with Fluid Motion, Wavelet Transform, Harmonic Wavelet, Fatigue Crack, Collision

\section{1. 暒言}

機械の高速化・高負荷化とともに，材料費削減や燃 費向上を目的とする軽量化が進むにつれ，使用する歯 車や軸，ボルトなどの機械要素の強度には，より多く の注意を払う必要が生じる. 特に, 機械要素に生じる き裂やボルトの緩みなどは機械の破壊にまで至る可能 性があり，その検出は重要な課題である.

信号処理方法の一つであるウェーブレット変換 ${ }^{(1)}$ は, 時間周波数解析を可能とする特徵を持ち, 機械要 素の異常検出法として, 配管腐食診断システム ${ }^{(2)} や$ 歯車の表面損傷診断 ${ }^{(3)}$ など，様々な分野での利用可 能性が研究されている. しかしながら，異常性を示す 信号が通常高周波成分に現れるため，本質的にノイズ の影響を受けやすく，異常性の検出に有効な信号成分 を残しつつノイズを除去するのは非常に困難である.

* 原稿受付 2004 年 12 月 13 日.

*1 正員, 九州大学大学院I学研究院 (-812-8581 福岡市東区 箱崎 $6-10-1)$.

*2 正員, 九州大学大学院工学麻。

*3 正員, 佐世保工業高等専門学校( - 857-1193 佐世保市沖新 町 1-1).

E mail : takumi (a mech.kyushu u.ac.jp
また，ウェーブレット変換には，対象とする波形の両 端を最大とする尾ひれ状のいつわりの波（End effects）が現れることが知られており，これも異常 信号検出の際に大きな妨げとなる.

本報では，対象を定常運転している機械の振動波形 とし, 周波数分解能に優れたハーモニックウェーブレ ットを適用することで，微小な異常信号を早期に検出 する振動診断システム ${ }^{(4)}$ の構筑を目的とする. その ために, 波形の定常性とハーモニックウェーブレット の特徴を十分に活かし, 診断に有効な信号成分を失う ことなく，ノイズおよびEnd effectsを十分に除去す る方法を新たに提案する.これにより，異常信号の早 期検出を妨げる大きな要素を取り除くことが可能とな る. 提案した手法の有効性を検証するため, はりの締 付ボルトの緩み, また, In-line 流力弾性振動で発生 する疲労き裂の検出実験を行った，両実験ともに検出 対象となるのは, 微小な衝撃により発生する非常に小 さな異常信号である.なお, In-line 流力弾性振動と は, 1995 年, 高速増殖炉「もんじゅ」において, 2 次 冷却系配管内の温度計鞘が疲労破壊に至った原因とし てよく知られる自励振動である. 


\section{2. ウェーブレット変换}

$2 \cdot 1$ ハーモニックウェーブレット ${ }^{(5)}$ 本報では 周波数分解能に優れたハーモニックウェーブレット変 換 (Harmonic wavelet transform : HWT) を用い る. HWT のマザー・ウェーブレットは, 以下に示 すスケーリング関数 $\phi(t)$ およびウェーブレット $\psi(t)$ か ら構成される.

$$
\begin{aligned}
& \phi(t)=\{\exp (i 2 \pi t)-1\} / i 2 \pi t \\
& \psi(t)=\{\exp (i 4 \pi t)-\exp (i 2 \pi t)\} / i 2 \pi t
\end{aligned}
$$

ここに, $i$ は虚数記号である. $\phi(t)$ および $\psi(t)$ のフー リエ変換 $\Phi(\omega)$ および $\Psi(\omega)$ は,

$$
\begin{aligned}
& \Phi(\omega)=\left\{\begin{array}{cc}
1 / 2 \pi & \text { for } \quad 0 \leq \omega<2 \pi \\
0 & \text { elsewhere }
\end{array}\right. \\
& \Psi(\omega)=\left\{\begin{array}{cc}
1 / 2 \pi & \text { for } 2 \pi \leq \omega<4 \pi \\
0 & \text { elsewhere }
\end{array}\right.
\end{aligned}
$$

で表され， $\psi\left(2^{j} t\right)$ とおけば, 式 $(4)$ から $\psi\left(2^{j} t\right)$ の占め る周波数成分は $2^{j} \times 2 \pi \leq \omega<2^{j} \times 4 \pi$ となる.ここに， $j=0,1, \cdots$ をウェーブレットのレベルと呼ぶ. HWT が優れた周波数分解能を持つ所以は，式(3),(4)に 示すように, $\phi(t), \psi\left(2^{j} t\right)$ が完全に分離された周波数 成分を持つことによる. さらに, 整数トランスレート を行った $\phi(t-k), \psi\left(2^{j} t-k\right)$ を考えると，これらは直 交性を持つため基底関数となり ${ }^{(5)}$ ，任意の信号波形 $f(t)$ を以下のように表すことができる.ただし，ここ で取扱う信号 $f(t)$ は実数であるとする.

$$
f(t)=\sum_{k=-\infty}^{\infty} a_{\phi, k} \phi(t-k)+\sum_{j=0}^{\infty} \sum_{k=-\infty}^{\infty} a_{j, k} \psi\left(2^{j} t-k\right)
$$$$
+c c
$$

ここに, $c c$ は右辺の総和に含まれる各要素の複素共 役である. 式(5)において複素共役を考慮しつつ, $k$ に関する総和を以下のようにおく.

$$
\begin{aligned}
& h(t)=\sum_{k=-\infty}^{\infty}\left\{a_{\phi, k} \phi(t-k)+c c\right\} \\
& g_{j}(t)=\sum_{k=-\infty}^{\infty}\left\{a_{j, k} \psi\left(2^{j} t-k\right)+c c\right\}
\end{aligned}
$$

$h(t)$ はゼ口周波数帯域 $(0 \leq \omega<2 \pi)$ の信号成分, $g_{j}(t)$ はレベル $j$ の周波数带域 $\left(2^{j} \times 2 \pi \leq \omega<\right.$ $2^{j} \times 4 \pi ）$ のウェーブレット成分を表す。これにより， 対象とする信号が, $f(t)=h(t)+g_{0}(t)+g_{1}(t)+\cdots$ と表さ れる. 実際に取扱う信号は離散化された有限個のデー タであり，データ総数 $N$ が信号解析でよく用いられ る $N=2^{n}$ ならば, ウェーブレットとして取り扱える レベルは $j=n-2$ が最高となる.このとき, $h(t)$ はフ ーリエ級数の定数項に一致し, 異常性を示す信号とし ては重要でないため,ここでは考慮しないことにする。
レベル $j$ のウェーブレット係数 $a_{j, k}$ は, $N=2^{n}$ の場合, 同じレベル $j$ の周波数成分を持つ複素フーリエ係数 $F_{m} \quad\left(2^{j} \leq m<2^{j+1}\right)$ と以下の関係を持つ.

$$
F_{m}=2^{-j} \sum_{k=-\infty}^{2^{j}-1} a_{j, k} \exp \left(-i 2 \pi m k / 2^{j}\right)
$$

式(8)から, $F_{m}$ は $a_{j, k}\left(k=0,1, \cdots, 2^{j-1}\right)$ のフーリエ 変換として表されていることがわかる．すなわち， $a_{j, k}$ は $F_{m}$ をフーリエ逆変換すれば求められる. さら に，データ数が $N=2^{n}$ であるため, $f(t) \rightarrow F_{m}$ のフー リエ変換, $F_{m} \rightarrow a_{j, k}$ のフーリエ逆変換ともに高速フ 一リエ変換（FFT）および逆変換（IFFT）のアル ゴリズムが適用でき，非常に効率的な計算が実行でき る. なお, 通常の時間周波数解析は, ウェーブレット 係数 $a_{j, k}$ の大きさを見ることで行われるが，本報では より詳細な解析を実行するため, 波形 $g_{j}(t)$ を表示し てその振幅変化を見ることにする.

$2 \cdot 2$ End Effects の除去 図 1(a)は, $N=2^{10}$ $=1024$ 個のデータからなる単一周波数成分の余弦波 であり, 1(b)はこの波形のレベル $7(n-3)$ の波形 $g_{7}$ である. 元々の余弦波はレベル 7 の周波数成分を 持たないが， $g_{7}$ には波形の両端を最大に尾ひれのよ うな波が生じる。これを End effects と呼び，信号中 に含まれる微小な異常信号を検出する際の妨げとなる。 End effects は，図1(a)のように波形の始点から終 点までが振動周期の整数倍でなく，始点と終点での不 連続性が主たる原因であり，フーリエ変換のギブス現 象に相当する． HWT のマザー・ウェーブレット $\psi(t)$ は長いサポートを持つため, End effectsの影響を受 けやすく，有効な異常信号の検出を行うには，この影 響をできるだけ除去する必要がある。サポートの短い マザー・ウェーブレットに対しては，End effects の 除去法 ${ }^{(6)}$ が提案されているが，サポートの長い HWT には有効でない，そこで本報では，対象がほ ぼ定常振動と見なせる信号に限定されるものの， HWT に発生する End effects を効果的に除去できる データ処理法を提案する.

信号波形の始点と終点での不連続性が End effects の主たる発生原因であるため, それらが連続である信 号にHWT を適用すれば，End effects はほとんど現 れない.しかし，この条件とデータ総数 $N=2^{n}$ を同 時に満足する信号を得るのは非常に困難である．そこ で, $N=2^{n}$ の条件は考慮から外し，始点と終点の連 続性のみを満足する信号を対象とする．例えば図 1(a)の 4 周期のみを対象とすれば, この部分のデー 夕数は $N^{\prime}=952$ であり $2^{n}$ の形ではない。通常用いら れる 2 進ウェーブレット(1) では, このようなデータ 


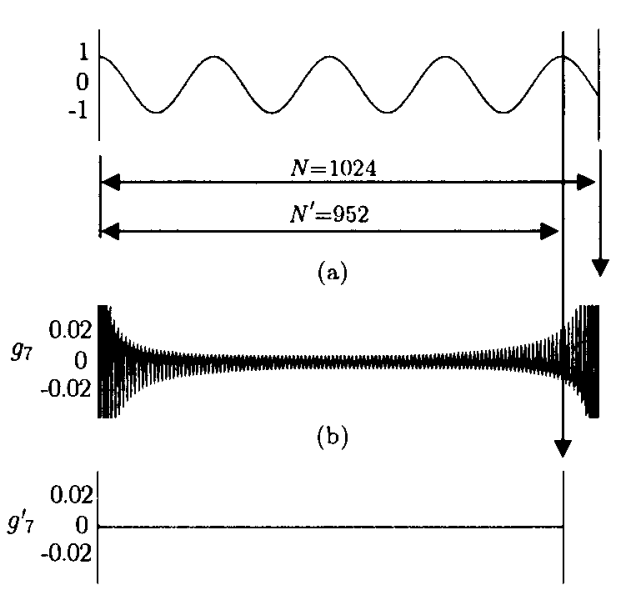

(c)

Fig.1 Example of end effects and removal of end effects for harmonic wavelet (a) Ideal signal plane of wavelet

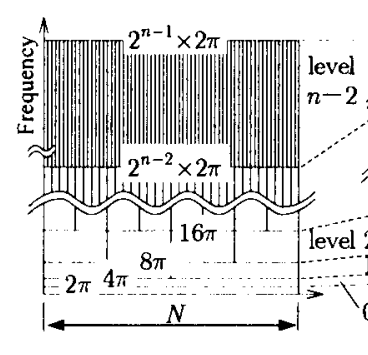

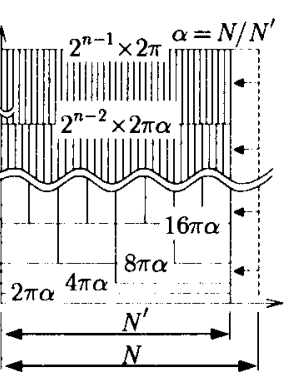

(b) Signal plane of the present method
Fig. 2 Comparison of signal planes of ideal wavelet transform and the present method

点数の取扱いは極めて困難である。しかしながら， HWT は，信号の複素フーリ工級数 $F_{m}$ さえ求められ れば，何らかの形で式 (8)を逆に解くことで実行可能 である．ただし， $F_{m}$ を求める際にFFTを使えない ため，一般的な爼散复素フーリエ变換を行う必要があ る.そのとき，デ一夕数が $N=2^{n}$ の場合と比較して 基本周波数が $2 \pi$ 加 $2 \pi \alpha\left(\alpha=N / N^{\prime}\right)$ 人変化し， HWT の時間一周波数平面も図 2(a)から 2(b)八変 化する.ここでは横軸を時間の代わりにデータ数 $N$ で表示している. 図 2(b)のレベル0から 0 -3の周波 数筙囲は $2^{j} \times 2 \pi \alpha \leq \omega<2^{j} \times 4 \pi \alpha$ となり，オクターブ の関係を満たしているので，式(8)で $2 \pi$ を $2 \pi \alpha$ に置 き換えた式が成立し， $a_{j, k}$ の計算に IFFT が利用でき る.しかしながら，レベル $n-2$ の周波数簌囲は，最 高次の周波数が固定されていることから $2^{n-2} \times 2 \pi \alpha$ $\leq \omega<2^{n-2} \times 4 \pi$ となり， $a_{j, k}$ を求めるための IFFT が 利用できない，式 $(8)$ を連立 1 次方程式として解けば

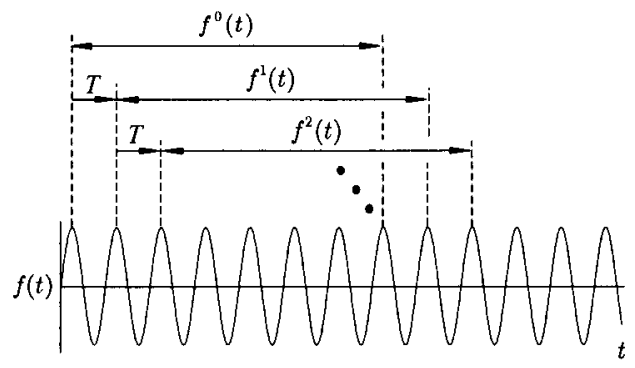

Fig.3 Method to extract waveforms for noise reduction

このレベルの $a_{j, k}$ も求められるが，計算の簡略化のた めここでは利用しないことにする. したがって，本手 法の最高レベル $n-3$ までで十分に異常性が恰出でき るよう，適度なサンプリング周期を用いることが必要 である。

$2^{n}$ 個でないデータを取扱う際の具体的な変更点は，

(1) $F_{m}$ の計算にはFFT でなく一般的な離散複素 フーリエ変換を用いる.

(2) レベル $n-2$ の成分は利用しない.

となる. 変更後のレベル $7(n-3)$ の波形 $g_{7}^{\prime}$ を図 1 (c)に示す. End effects がほぼ完全に除去され，余 弦波がこのレベルに有意な信号成分を持たないことが 明確に示される.レベル 7 以外の成分にも End effectsが現れないことを確認している．HWT の性 質を活かしたこのような取扱いは，本手法独自の優れ た点である。

$2 \cdot 3$ ノイズの低滅 ウェーブレット変換の特徴 から, 微小な異常信号の多くは高周波のウェーブレッ 卜成分に含まれることが知られている。しかし，実際 に計測された信号は高周波領域に多くのノイズを含み， 微小な異常信号の検出を難しくする．そのため，ノイ ズを振動波形から低减する工夫が必要となる。ここで は，異常信号は主要な定常周波数成分と同期して現え ると考え，ノイズはホワイトノイズに近いとする．以 下に，それらの特徴を利用したノイズ低减法を示す。

図 3 に示すような，定常振動波形 $f(t)$ を考える.こ の波形から，End effects を避けるため雨端間が振動 周期の整数倍となる波形 $f^{0}(t)$ を抽出する. $f^{0}(t)$ に含 まれる主要周波数成分の波数は，HWTで取扱いた い周波数範囲とデータ量とのバランスを考虑して，問 題によって適当に設定する. $f^{0}(t)$ を構成するデータ 数 $N^{\prime}$ は通常 $2^{n}$ 個ではない，次に，波形 $f^{0}(t)$ を抽出 した区間よりも, 主要な周波数の 1 周期分 $T$ だけ平 行移動した波形 $f^{1}(t)$ を抽出する.この平行移動のパ ラメータ $T$ は, 波形 $f^{0}(t)$ と $f^{1}(t)$ との自己相関が最大 となる $t$ とする. 以降, 同様に平行移動を行うことで, 
$M$ 個の波形 $f^{0}(t), f^{1}(t), \cdots, f^{M-1}(t)$ を抽出し，それぞ れに一般的な離散複素フーリエ変換を行って複素フー リ工係数 $F_{m}^{0}, F_{m}^{1}, \cdots, F_{m}^{M-1}\left(m=0, \cdots, N^{\prime}-1\right)$ を求め る. 最終的に，これらを平均したフーリエ係数：

$$
F_{m}^{a v}=\left(F_{m}^{0}+F_{m}^{1}+\cdots+F_{m}^{M-1}\right) / M
$$

を求め, これを逆変換した波形:

$$
f^{a v}(t)=\sum_{m=0}^{N^{\prime}-1} F_{m}^{a v} \exp (i 2 \pi \alpha m t)
$$

にHWT を適用する． $f^{a v}(t)$ は，フーリエ係数を平均 化することでランダムなノイズが相殺され，定常信号 と同期する重要な要素のみが残った波形となり，有効 な HWT が実現できる．なお，実際の HWT では $f^{a v}(t)$ を求める必要はなく，2・2 節で述べたように, $F_{m}^{a v}$ にIFFT を適用すればウェーブレット係数（レベ ル $0 \sim n-3)$ を求めることができる.

\section{3. ボルトの緩みによる異常信号の検出実験}

$3 \cdot 1$ 目 的 はりを締結するボルトが緩むと， 締結している結合金具とはりの間に微小なガタによる 衝突やすべりが生じる. 2 章で説明した HWT をはり の加速度波形に適用し，この現象の際に発生する信号 を，締付ボルトの緩み（衝擊の発生）のどの段階で検 出できるかをテーマに実験を行う。

3.2 実験装置および条件 実験装置を図 4 に示 す、装置は，結合金具とボルト（M8）を用いて互い に締結した同じ長さの 2 本の $\mathrm{S} 45 \mathrm{C}$ 製はり（厚さ $3 \mathrm{~mm}$ ）とした. 締結したはりの両端はしっかりと固 定した. 実験では，図 5 に示す位置のボルトの締付卜 ルクを段階的 $(2,4,6,8 \mathrm{Nm})$ に変化させた．ガタが ボルトの締付トルク変化によって発生しやすいように, トルクを変化させるボルトのすぐ下のボルトは取り除 いてある. また，その他のボルトは $20 \mathrm{Nm}$ 以上のト ルクで締付けた．それぞれの締付トルクにおいて，励 振用マグネットによりはりを 1 次の固有振動数 $(6.4 \mathrm{~Hz})$ で共振させ，そのときのはりの加速度を図 5 に示寸位置に貼付した加速度ピックアップにより測 定した．得られた加速度データを，チャージアンプを

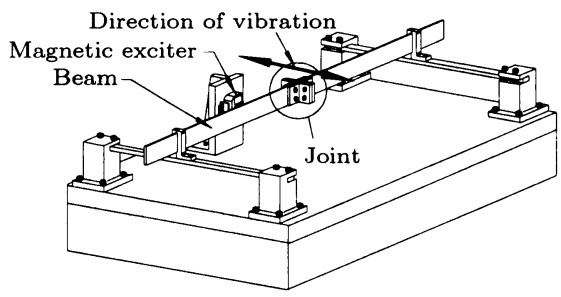

Fig.4 Outline of experimental apparatus
通してデータレコーダに貯えた後，パーソナルコンピ ュータ（PC）に取り込み，HWTを実行した。サン プリング周期は 0.2 ミリ秒, 取り込むデータ長さは 30 秒とし, 図 3 に示寸 HWT を適用する基本波形 $f^{0}(t)$ は, 主要振動数（1 次の固有振動数）の波形 5 波 分とした. 取り込んだ 30 秒間のデータから $f^{0}(t)$ 〜 $f^{63}(t)$ の 64 波形を抽出し, ノイズ低减のための平均 化を行った.

3.3 実験および解析結果 図 6(a)〜6(d)にボ ルトの締付トルクが $2 ， 4 ， 6 ， 8 \mathrm{Nm}$ のときの結果を示 す．図 6(a)において，上図はノイズを低減させた加 速度振動波形データ $f^{a v}(t) \quad\left(N^{\prime} \leq 2^{12}\right)$ である。この データでの最高レベルは $n-3=9 ; n=12$ であり，図 6 下図は上図に対する, 最高レベル 9 の波形 $g_{9}^{\prime}(t)$ (周波数範囲約 $625 \sim 1250 \mathrm{~Hz}$ )，レベル 8 の波形

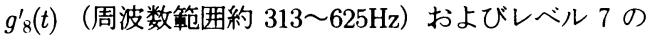
波形 $g_{7}^{\prime}(t)$ （周波数範囲約 $156 \sim 313 \mathrm{~Hz}$ ) である.ただ し，本報では異常信号の大きさが定量的に判断できる ように，主要な定常周波数成分の振幅（V) が 1 とな るように正規化を行った．この結果から，最高レベル 9 で最も顕著に異常信号を検出できることがわかる. これは，検出された異常信号がボルトの緩みにより発 生する衝突（衝撃）を原因とするためである，よって， 図 6(b)〜6(d)には，上図にノイズを低减させた加速 度振動波形データ $f^{a v}(t)$ ，下図に上図に対する最高レ ベル 9 の波形 $g_{9}^{\prime}(t)$ のみを表示した.

図 6(a)〜6(c)の締付トルクが, 2, 4, 6Nm では, それぞれすべてに 1 周期に 2 回の微小な異常信号を検 出した. 特に, 図 6(c)のように, 加速度振動波形デ 一タからは，まったく異常性を確認できないが，本報 のノイズ低减法およびHWT を用いることで，微小 な異常信号が検出できた. 1 周期中 2 回の異常信号の 大きさが異なるのは，はりが励振用マグネットに近づ く場合と離れる場合で，結合金具とはりの衝突の強さ やすべりの大きさが異なることを表していると思われ る. 締付トルクが $8 \mathrm{Nm}$ になると，図 6(d)に示すよ うにウェーブレット成分に異常信号は見られない。こ

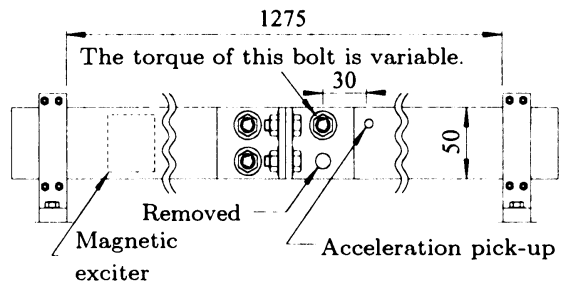

Fig.5 Front view of experimental apparatus [unit: $\mathrm{mm}$ ] 


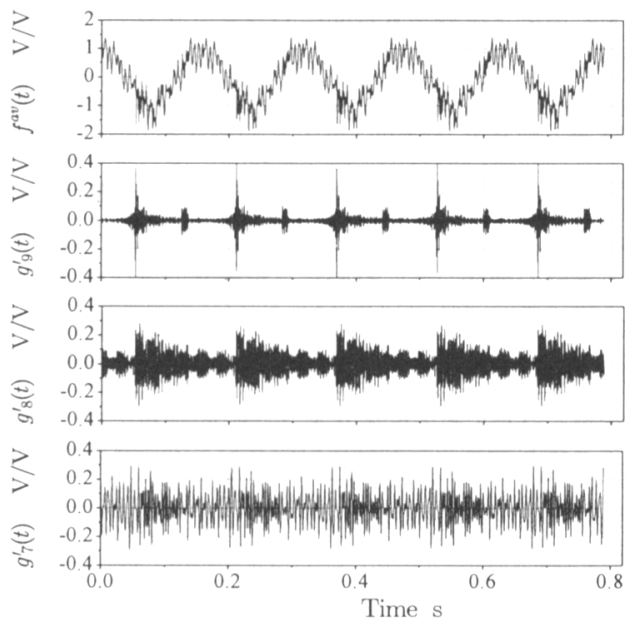

Fig.6 (a) 2Nm
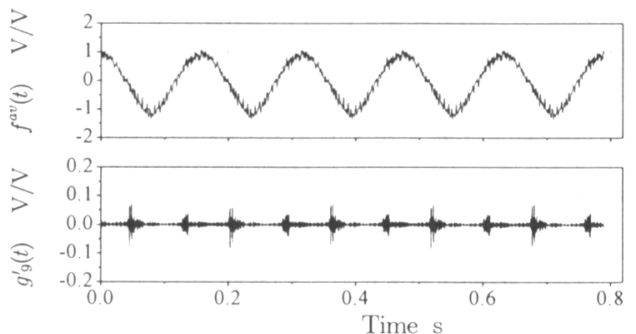

Fig.6 (b) $4 \mathrm{Nm}$

のことから，締付トルクが $8 \mathrm{Nm}$ では，ボルトにより 結合金具とはりがしつかりと固定され，ガタのない状 態になったと考えられる。

次に，ノイズ低減，および本報の HWT の有用性 を確認するために，楴付トルクが $6 \mathrm{Nm}$ の加速度振動 波形に対して, End effects 除去のための波形抽出も, ノイズ低減のための平均化も行わずに HWTを実行 する。その結果を図 7 に示す。図 7 上図は加速度振動 波形デー夕 $f(t)$ であり，デー夕数は通常用いられる2 のべき乗の形で $N=2^{12}=4096$ 個, 主要成分の波数 は5 波よりやや多い。下図はレベル $9(n-3)$ の波形 $g_{9}(t)$ （周波数範讲約 $625 \sim 1250 \mathrm{~Hz}$ ） である. 図 7 か らわかるように, ウェーブレット成分には, 多くの) イズおよびEnd effects が混在し，異常信号を明確に 検出することはできない.

この実験により，実際の実験データにおいても，波 形がほぼ主要な振動数成分からなる定常振動波形であ れば，始点から終点までが主要な振動周期の整数倍と なる定常波形を抽出することでEnd effects が除去で き，提案したノイズ低减法を用いることで，波形から 大幅にノイズが低減されることがわかった。 その結果, 加速度振動波形からはまったく確認できない小さなガ

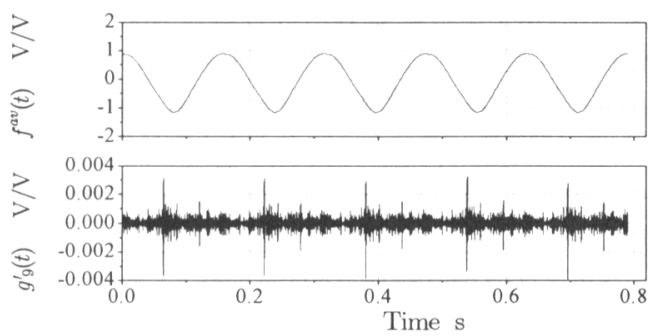

Fig.6 (c) $6 \mathrm{Nm}$

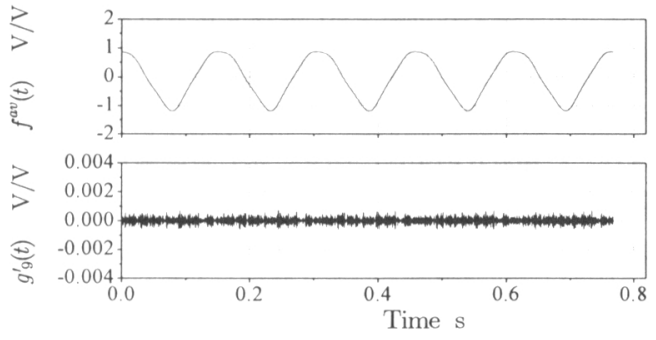

Fig.6 (d) $8 \mathrm{Nm}$

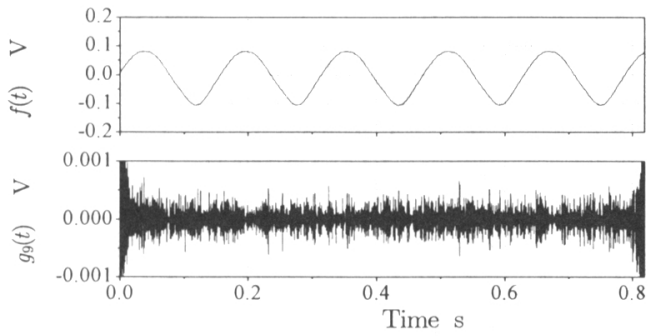

Fig. 7 Without noise reduction $(6 \mathrm{Nm})$

タによる衝突や寸べりを原因とする微小な異常信号を， HWT により検出可能であることが示された.

\section{In-line 流力弾性振動によって発生する 疲労き裂の検出実験}

4·1 目 的 流体の一様流れの中に弾性体が置 かれると，流体励起振動がおこることがある。特に， 円柱形の弾性体が, 図 8 に示すように, 無次元流速 $V_{r}=U / D f_{n}=1.2 \sim 2.5$ （ただし，U は一様流れの流 速, $D$ は円柱形弹性体の直径, $f_{n}$ は流体中の弾性体 の固有振動数）の流れの中に置かれた場合（領域(1)）， 弾性体の後流で双子渦が発生し, In-line 流力弾性振 動がおこる，高速増殖炬「もんじゅ」の温度計に発生 したこの In-line 流力弾性振動は高振動数で振動する ため, 弾性体に切欠きや微小穴などの欠陥を含む場合 は短時間で疲労破壊に至る。そこで, このような疲労 破壊を防止する技術の一環として, HWT が疲労き 裂の発生を早期に検出できるかをテーマに実験を行う。

$4 \cdot 2$ 試験片使用材料は S45C 圧延丸棒である. 
図 9 に示すように試験円柱は直径 $10 \mathrm{~mm}$ ，長さ $120 \mathrm{~mm}$ であり，土台にねじで固定する形式とした。 き裂の発生箇所を限定するために，円柱の根元部を砂 時計型とし，さらにその最小直径部に微小ドリルによ って直径 $d$, 樑さ $h$ の人工微小穴 $(d=h=100 \mu \mathrm{m})$ をあけた、機械加工後，加工による残留応力を除去す るために $600^{\circ} \mathrm{Cで} 1$ 時間の真空焼きなましを行った.

$4 \cdot 3$ 実験装置および条件実験装置を図 10 , 実 験装置の試験部を図 11 に示す。装置は，横断面 $100 \mathrm{~mm} \times 100 \mathrm{~mm}$ ，長さ $2 \mathrm{~m}$ のアクリル製角管の中を 渦巻きポンプにより水が一様に流れるようになってい る、アクリル製角管の中央上部に直径 $60 \mathrm{~mm}$ の穴を 開け，一様流えの中に，図 9 に示した試験片を置く。 試験片の根元部は S45C 製土台にしっかりとねじ込ま れており，さらにその土台は動かないように固定され ている，また，穴から水が漏れるのを防ぐために，土

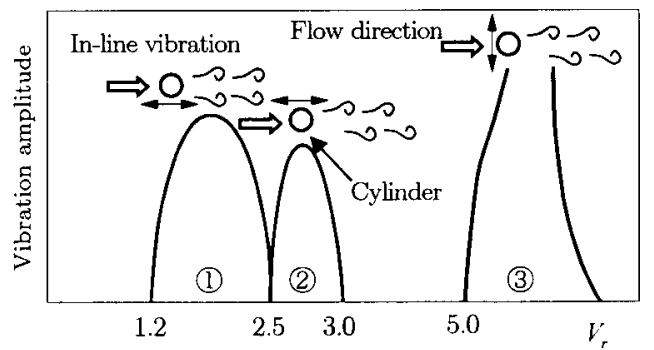

Fig.8 Relationship between $V$, and amplitude

(1), (2) : Vibration parallel to flow

(3) : Vibration transverse to flow caused by Karman vortex

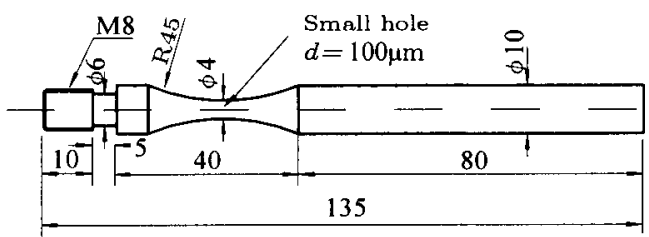

Fig.9 Shape and dimensions of specimen [unit: $\mathrm{mm}$ ]
台とアクリル製角管の間に○リングを挟む.

In-line 流力弾性振動を起こすためには，試験片を 無次元流速 $V_{r}=1.2 \sim 2.5$ の流れの中に晴く必要がある. 本報では，水中での試験片の固有振動数を $f_{n}=$ $153.8 \mathrm{~Hz}$ ，試験片の直径を $D=0.01 \mathrm{~m} ， 一$ 様流れの流 速を $U=3.2 \mathrm{~m} / \mathrm{s}$ に設定して， $V_{r}=U / D f_{n}=2.1$ とし て実験を開始した，訊験片の振動測定は，簡易防水を 施した加速度ピックアップにより行った．図 11 に示 すように，加速度ピックアップのケーブルを，アクリ ル板と○リングによりできた隙間から土台に開けた 穴を通してチャージアンプにつないだ，その後，加速 度データをデータレコーダに眝えた後，PCに取り込 み，HWT を実行した。試験片の振動数が速いため， サンプリング周期は 0.05 ミリ秒，取り込むらデータ長 さは 2 秒とした。 HWTの適用波形は，発生した振 動波形 7 波分とし，ノイズ低減のための平均化は $f^{0}(t) \sim f^{127}(t)$ までの 128 波形を用いた。

4.4 実験および解析結果 図 12 に In-line 流力 弹性振動の実験で得られた加速度振動波形データの FFT 分析から求めた，試験片の水中での振動数変化 を示す、実験開始後 44 分あたりから，き裂進展にと もない，振動数が変化している様子がわかる.

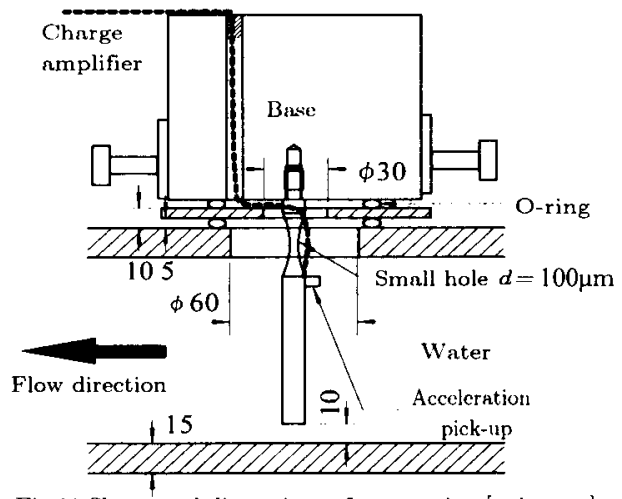

Fig.11 Shape and dimensions of test section [unit: $\mathrm{mm}$ ]

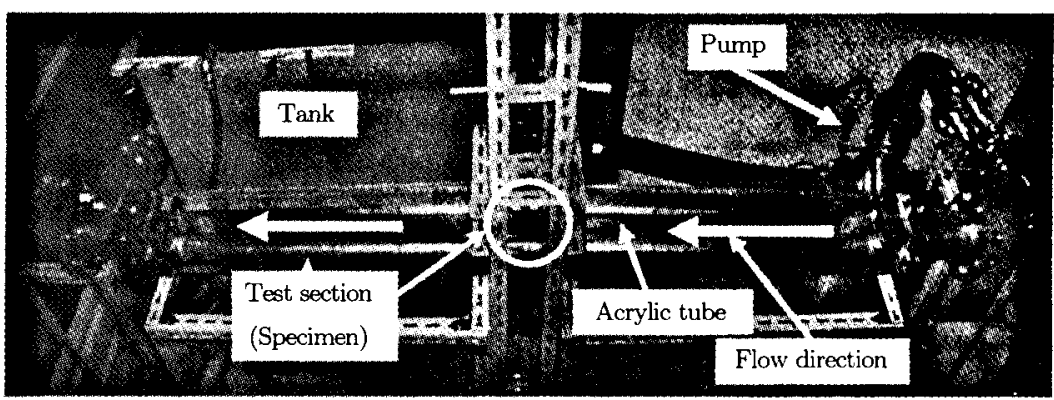

Fig.10 Outline of experimental apparatus 
そこで,この加速度振動波形データに対して HWT を適用し，き裂から発生する微小な異常信号 を検出する. 図 13 にHWT の結果の一例を示す. 図 13(a)～13(e)の上図はノイズを低減させた加速度振 動波形データ $f^{a v}(t) \quad\left(N^{\prime} \leq 2^{10}\right)$ である.このデータ での最高レベルは $n-3=7 ; n=10$ であり, 図 13 下 図は上図に対する, 最高レベル 7 の波形 $g_{7}^{\prime}(t)$ （周波 数範囲約 $2500 \sim 5000 \mathrm{~Hz}$ ) である.ただし，第 3 章と 同様に振動波形データの正規化を行った。 また,この 実験では，異常信号の微小さやノイズの大きさの関係 から, 最高レベル 7 以外のウェーブレット成分からで は異常信号の確認は難しかった。

HWT の結果を見ると, 図 13(a)の実験開始後 44 分のウェーブレット成分からは, 明らかな異常信号は 見られない，また，実験開始後 0 分から40 分におい ても同様に異常信号を確認寸ることはできなかった. しかし, 振動数が変化し始めた実験開始後 48 分（図

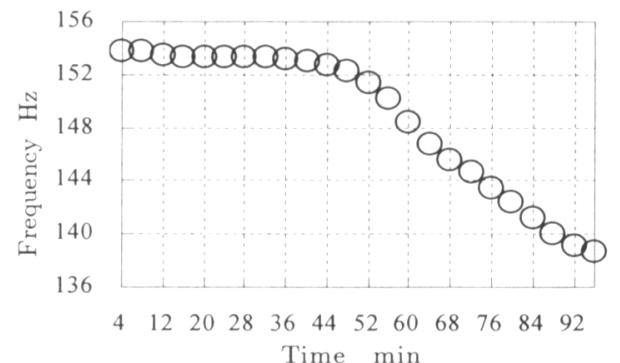

Fig.12 Frequency of specimen in water

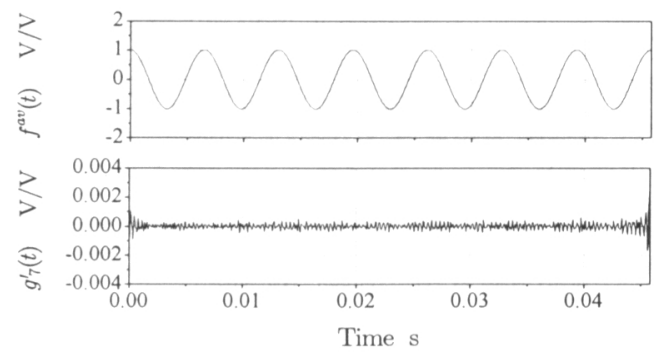

Fig.13(a) Lapse of 44 minutes

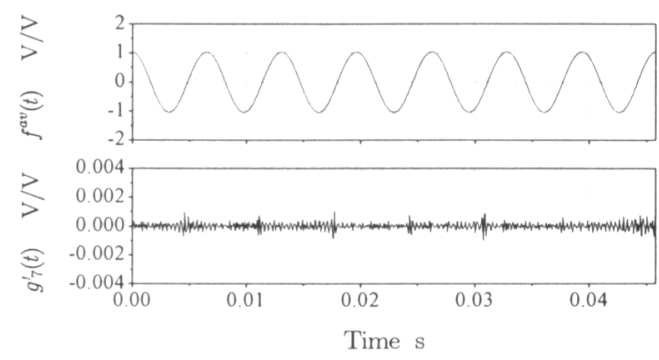

Fig.13(b) Lapse of 48 minutes
12 参照）のウェーブレット成分では, 図 13(b)に示 すように, 微小な異常信号を示す周期的なピークが 1 周期あたり 1 つ見られる. この異常信号を示すピーク は, 時間の経過とともに大きくなり, 実験開始後 64 分, あるいは図 $13(\mathrm{c})$ に示す実験開始後 68 分で最大 となる。この周期的な異常信号は，加速度波形上での 出現位置が，開口していたき裂が閉口すると考えられ る位置にあることと, 最高レベル 7 で検出されたこと から，第 3 章の衝突による異常信号と同様に，き裂閉 口時の衝突から発生していると判断される.

実験開始後 68 分まではき裂進展にともない, 異常 信号が大きくなっていると思われる．しかしながら， 68 分以降, 図 13(d), 13(e)に示すように, 異常信号 を示すピークは徐々に小さくなっていく，これは，今 回の実験開始条件が無次元流速 $V_{r}=U / D f_{n}=2.1$ であ ることを考えると, 試験片の固有振動数低下（無次元 流速の増加）により, 試験片の振幅が小さくなるため

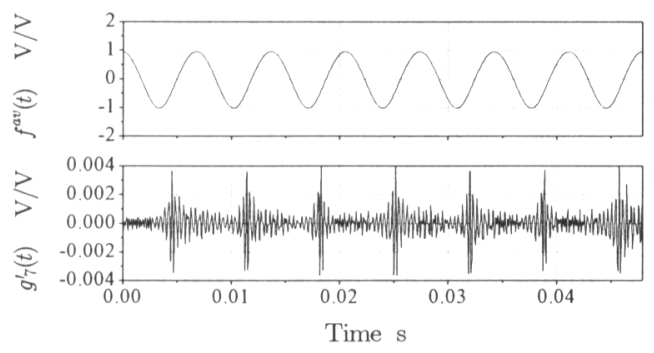

Fig.13(c) Lapse of 68 minutes

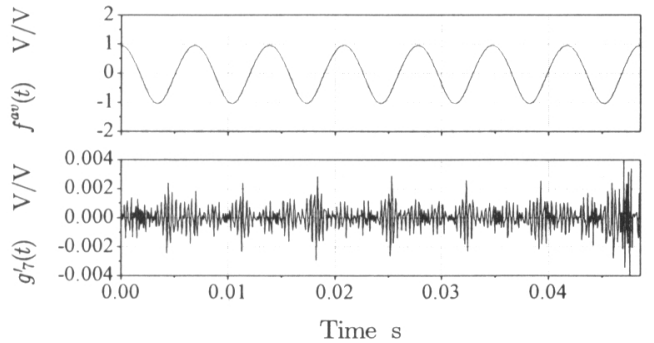

Fig.13(d) Lapse of 76 minutes

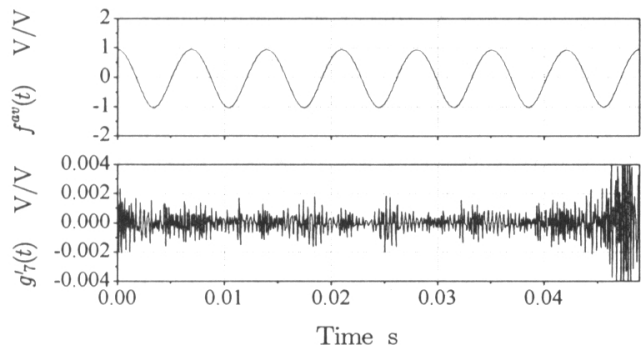

Fig.13(e) Lapse of 80 minutes 


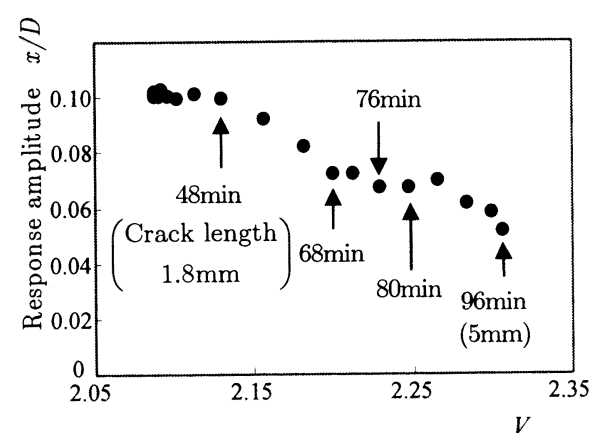

Fig.14 Relationship between non-dimensional flow velocity and response amplitude

に（図 8 参照），き裂の衝突が弱くなったためと考え られる. そこで実験中の試験片の振幅変化と無次元 流速の関係を図 14 に示す. 横軸は実験中の無次元流 速 $V_{r}$ ，縦軸は無次元振幅 $x / D$ である.ここに， $x$ は試験片円筒部が剛体で，き裂発生部分のみがひずむ とみなしたときの，加速度信号から推定した試験片先 端の振幅， $D$ は試験片直径である. 図 14 から, き裂 が進展し, 無次元流速が増加するのにともない, 試験 片の振幅が減少していることがわかる. したがって， 68 分以降, 異常信号が小さくなるのは, 試験片の振 幅が小さくなったことにより，き裂の衝突が弱くなっ たためと考えられる.

この実験から，本報で提案したHWTを用いれば, In-line 流力弾性振動によって発生する疲労き裂を検 出できることがわかった。 また，同じ実験装置を用い た実験結果 ${ }^{(7)}$ の試験片の固有振動数変化と周方向き 裂長さの関係図を参考にすれば，図 13(b)の実験開 始後 48 分での周方向き裂長さが $1.8 \mathrm{~mm}$ 以下と微小で あることが推定される. 一方，実験を終了した 96 分 では，周方向き裂長さは $5 \mathrm{~mm}$ に達していた.

\section{5. 結言}

ウェーブレット変換を用いて，ボルトの緩みおよび In-line 流力弾性振動によって発生する疲労き裂の早 期検出を目指し，定常信号波形を対象として，実験お よび解析を行った．得られた結果を以下にまとめる.

（1）ウェーブレット変換で問題となる End effects を除去するため, 始点から終点までが主要な 振動周期の整数倍となる定常波形を解析対象とした.
その際，データ数が 2 のべき乗とならない問題点を， ハーモニックウェーブレットの特徵を活かし, 高速フ 一リエ変換の代わりに一般的な離散複素フーリエ変換 を用いることで解決した。

（2）解析対象である主要振動周期の整数倍となる 定常波形を，実際に計測された振動波形から複数個取 り出し，それぞれの波形から求めたフーリエ係数を平 均化してハーモニックウェーブレットを実行した。 こ れにより，異常信号検出の妨げとなる高周波領域の， イズが軽减され，明確な診断が可能となった。

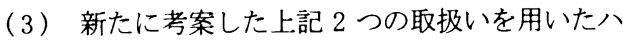
一モニックウェーブレット変換を, 締付ボルトに緩み が生じたはりの定常振動波形, In-line 流力弾性振動 によって疲労き裂を発生させた試験片の定常振動波形 に適用した，両者とも，目視ではまったく異常性を確 認できない波形からでも，微小な衝撃によると考えら れる異常信号を検出することができた.

\section{謝 辞}

本報は核然料サイクル公募型研究として核燃料サイ クル開発機構と九州大学との共同研究により行われた ものであり，関係各位に謝意を表す。

\section{文献}

（1）棉原進，ウェーヴレットビギナーズガイド，東京電機大学 出版局, (1995).

（2）後藤陽一・細貝英実·原文雄·阿部靖則・田中祥夫. ウェーブ レット変換を用いた配管腐食診断システム、练論. 64-625. C (1998), 3342-3347.

（3）吉田彰・大上祐司・木脇祐二.大西康資・本郷俊明・楊振亮. ウェーブレット変換を用いた歯車動的性能変化による菌 面損甥診断(歯面損傷診断に対するウェーブレット変換の 有用性), 機論, 65-636, C (1999), 3362-3367.

（4）曽根彰·山本鎮男·有馬幸藏·増田新·中岡明，ウェーブレッ 卜変換を用いた機械・樓造物のヘルスモニタリングシステ ム(正規直交ウェーブレットの生成と断続的な異常信号の 検出), 機論, 61-586, C (1995). 2340-2346.

(5) David E. Newland, Harmonic wavelet antalysis. Procerdings of the Royal Socicty of London. A443. (1993). 2113-225.

(6) T.Kijewski and A.Karcem, On the presence of end effucts and their melioration in wavelet-bascol analysis, Journal of Sourkl and Vibration, 256(6), (2002), 980-988.

（7）小田原悟·村上敬宜·井上雅弘・末岡㳯男, In-line 流力弹性振 動による配管系の疲労破壊現象の解明と早期寿命予測法 の確立, 機論, 70-690, A (2004), 212-220. 